\title{
Implementation of a project for the organic agriculture experience in rural schools: climate studies, vegetable gardens, and free-range poultry production
}

\author{
Adriana Maria dos Santos (iD) - Marina Paiva Baracuhy • \\ Dermeval Araújo Furtado (iD - Fabiana Terezinha Leal de Morais - Adriano da Silva Félix
}

AM Santos (Corresponding author) - MP Baracuhy - DA

email: ttstadriana@gmail.com

Furtado - FTL Morais - AS Félix

Agricultural Engineering Academic Unit, Universidade

Federal de Campina Grande (UFCG), PB, Brazil.

Received: July 31, 2018 • Revised: November 15, 2018 • Accepted: November 15, 2018

\begin{abstract}
The aim of this study was the implementation of school vegetable gardens using recyclable materials, as a methodological tool and interdisciplinary practices related to family agriculture. A descriptive methodology and field study was used. The community's wishes on the school were diagnosed, and recyclable materials that could be inappropriately discarded in the environment were used. For better representation was used AutoCAD software. Through this study, it was possible to plan two types of vegetable gardens (nursery bed and mandala style). The nursery bed will be produced greens and vegetables and, for the mandala type a study was developed for the adequacy of vegetable and animal production with the use of equipment: a pet bottle greenhouse for the seedlings production, and a mobile chicken coop (animal husbandry) on the vacant ground for the ground preparation, and a earthworm, which will be used as composting in deterioration process of organic matter from and transforming this waste into fertilizer for the flowerbed. The crops used will be greens and vegetables for school feeding and production of fruit tree seedlings, which will be destined to the community. Will still have instruments for meteorological studies (pluviometer and, dry bulb and wet bulb thermometer). The activities carried out in the vegetable garden contribute to the modification of students' habits and attitudes about their perception of nature, the awareness formation of respect and care, the need to conserve the environment and stimulate the quest for improving the life quality and, in others ways to see the activities carried out by their own parents in the field.
\end{abstract}

Keywords: agroecology, food production, sustainability, waste

\section{Introduction}

In view of the constant technological changes in agriculture and food production, especially in the family agriculture, associated with the climatic changes, the uncertainties of economically, socially, politically and technologically correct agriculture, as well as the absence of agricultural practices in the experience of young's in rural communities, there is a concern about the future of world agriculture and food production (Adeokun 2017), with similar concerns being raised in Brazil. In Nigeria, the idea that agricultural activity, especially in rural areas, is undervalued by young and offers few benefits to its practitioners (Brumer 2006), suggests that there is a rather negative view of the imaginary of the rural youths, a fact that, in the last instance, reproduces the dominant stigma that rural spaces represent the place of "non-development", of the archaic, of the traditional.

According to Guthman (2014) for food production, students, in the exercise of citizenship or as future agricultural workers, will be better able to understand the debates and controversies that underlie the production, creation, and commercialization of agricultural products. In this way, recognizing the limits and possibilities of models, both intensive production and alternative models, these being devalued and disseminated (family agriculture, agroforestry production, etc.), as well as recognizing the various aspects (environmental, scientific, political, economic, cultural, etc.). These factors are present in different models of food production and to understand the different teaching tools and flexible learning, permaculture-based, that school vegetable gardens can provide.

One of the alternatives to increase the perception about activities in the agricultural environment and the care with the environment is the use of school vegetable garden. This alternative can serve as a food source and didactic activities, offering advantages to the communities involved, such as obtaining quality food, low cost, and school involvement in 
feeding and health programs (Arruda et al 2017). This also contributes to the knowledge of the "3'Rs" (reduce, reuse and recycle), integration of the school community in socialenvironmental activities, encouraging of organic foods consumption, providing students with agroecological practices for food production, so that they can be transmitted to their families and, consequently, to apply them in home or community vegetable gardens (Oliveira et al 2001).

In this context, this research aims at the implementation of school vegetable gardens, using recyclable materials, with the intention of contributing to the conscious citizens' formation and able to reflect on the socioenvironmental issues, and this subsidy as a methodological instrument to interdisciplinary practices of related activities family agriculture.

\section{Materials and Methods}

\section{Study area}

The study was carried out at the Delfino José dos Santos school, located in Lagoinha, municipality of Água Branca, semi-arid region of Paraiba (Brazil), with a geographical location of $-7^{\circ} 43^{\prime} 20^{\prime \prime}$ in latitude and $-37^{\circ} 62^{\prime} 83^{\prime \prime}$ in longitude. The air temperature ranging from 8,0 and 30,0 ${ }^{\circ} \mathrm{C}$, irregular rainfall, with annual averages of $719.6 \mathrm{~mm}$.year ${ }^{-}$ 1 .

The school serves more than 400 students from rural areas, the surrounding village, and surrounding properties, with agricultural production (maize, beans, rice, vegetables, and small fruits) being the main economic activity in the region, with growing bee honey production.

During meeting and interviews with parents and local farmers, they were anxious that the school should develop activities that value the productive culture of the region, where, through a request made by the Municipal Council for Sustainable Development (CMDS), studies were started of the problem presented. The methodology approached were bibliographic studies and local visitation, accompanied by CMDS representative in the school and communities contemplated in its surroundings. During these visits, it was diagnosed that among the demands of the community, the community vegetable gardens stood out, with concern for the fertilization type, vegetable choice, management of the vegetable garden, etc. As well, this, other agricultural activities, such as composting, fruit production and products of animal origin, always highlighting the sustainability and use of recycled products.

\section{Data collection}

The first stage of the research to elaborate and construct school vegetable gardens that attend the children and adolescents to the experience of agricultural and environmental practices for vegetal and animal production, was a research on the types of vegetable gardens and vegetables to be cultivated, adapted fruit trees the region were choice, management options to be inserted. In addition, the animals that were most adapted to the region's climate were chosen and easy handling and rearing, using low-cost construction materials and means to spread social actions to the community and farmers in the region.

After analysis of the available land, we chose to construct two types of vegetable gardens. The first being the vegetable garden and the second in the mandala style, and only the first vegetable garden was installed in the project. For its preparation and installation, 32 tires were recycled by the local community, in several sizes, to enlarge the spaces for planting, where the land was fertilized with cattle manure and prepared for the vegetable planting (Figure 1). The vegetable garden was installed in the space between the canteen and school wall, in an average space of $8 \mathrm{~m}$ in length and $2.0 \mathrm{~m}$ in width. For irrigation during drought periods, the school has a multisport court with a covered area of more than $10.22 \mathrm{~m}^{2}$, used to collect rainwater and stored a tank of 12,000 liters.

The mandalla vegetable garden was planned to be constructed with 2 circles of 2 meters wide, a greenhouse will be built in the center of the mandalla. A mobile henhouse and a small earthworm / Composting unit will be built, which will be moved on to the beds without planting (before planting and post-harvest), fertilizing the soil with manure and aerating with scratch of hens

It is noteworthy that in this vegetable garden the important thing is not its size, but the diversity of its cultivation. The main idea is to manage, in a balanced way, the soil and other natural resources through a harmonized work with nature and, as the vegetable garden will be located in the school dependences, the construction and management can be used as an enrichment activity for the learning of the classrooms (Santos 2009; Nutall 2008).

For the vegetable gardens preparation will be used recyclable materials, through solid waste characterization, materials that were discarded by local population, without proper destination to the environment:

Tires - used in the vegetable garden "nursery bed type".

Pet bottles - Will be used to demarcate the mandala vegetable garden and store rainwater for irrigation through dripping, pluviometer, and bird feeder.

$\square$ Disposable cups - Seed pots and small seedlings in the greenhouse.

$\square$ Timber from solid construction waste - Structural base for greenhouse and hen house, stand for pluviometer and base for greenhouse thermometer.

$\checkmark$ Paper - Fertilizer and, nursery bed bases.

$\neg$ Tetra Pak Boxes - Henhouse roof. 
Organic wastes from food production at school - Fertilizer, hen feed, slurry production and earthworm feeding.

$\square$ Gray water from school feeding: Irrigation and fertilization.

\section{Vegetables and animals employed}

Vegetable production: vegetables and tubers will be produced in the vegetable gardens; in the greenhouse will be produced fruit seedlings of easy adaptation to the Brazilian semiarid, such as Cashew - Anacardium occidentale; umbu Phytolacca dioica; pitomba - Spondias purpurea, pine cone Annona squamosa and coco Catolé - Syagrus cearensi; and plants with potential to produce flowers to facilitate the bees work in the honey production, like the hose - Anarcadiaceae, among others. In the animal production, the free-range hens (Gallus gallus domesticus), typical of the region, was chosen because it is small and guarantees the meat and eggs production.

\section{Climate studies}

According to Salgueiro (2005), it can be defined as the hydrology part that deals with the processes by which one can measure or evaluate values that represent or have the idea of the size of a precipitation event in a region or hydrographic basin area.

The pluviometer is an equipment with a horizontal catchment surface and a tank for accumulating collected water connected to that catchment area. There are several pluviometer models in use in the world. In Brazil, the most widespread is the French standard known as Ville de Paris (Silva 2008).

According to ASHRAE (2005), the temperature can be characterized by Dry Bulb Temperature (DBT, ${ }^{\circ} \mathrm{C}$ ) indicating the energy amount in the heat form contained in the air, and the Wet bulb temperature (WBT, ${ }^{\circ} \mathrm{C}$ ) that indicates the energy amount in the heat form contained in moist air. This is associated with the lowest temperature at which liquid water transforms into vapor (evaporation temperature) for a given water amount contained in the air (see specific moisture). It also lets you define the dew point condition and the partial water vapor pressure.

These data can be obtained from mercury thermometer for dry bulb temperature and mercury thermometer with its tip in contact with cotton soaked in distilled water for wet bulb temperature.

\section{Results and Discussion}

As an environmental education form and safety measures, for children's access, the project highlights the need to enter the vegetable garden and other facilities with closed shoes, gloves, and cap, to be offered by the school or convened agencies.
In the nursery bed vegetable gardens (Figure 1 and 2) the following vegetables were planted: tomato, chili, chives, lettuce, coriander, basil, beet, and onion. This planting was carried out by students under the supervision of an EMATER/PB agricultural technician and local agriculturers. The produced vegetables are being used in the students feeding and serving as a showcase for other educational establishments and other agriculturers in the region.

In the educational context, adopting the model of living with projects that seek other production and consumption forms more sustainable is fundamental to re-signify time, space and social relations of learners. The irrigation system occurred through hand irrigators, made by the students in the two shifts, where the morning students irrigate at this time and those of the afternoon irrigate at end of the period.

The Mandala vegetable garden (Figure 3) allows for sustainable production and environmental protection, which provides an excellent agriculture model for children and rural producers. In addition to the vegetable organic production, harmonization and the beauty of the environment are also the results of this production model (Almeida et al 2012; Nuttall 2008). The Mandala vegetable garden uses its own natural resources, making the most of the local environmental elements (water, soil, sun, wind and native vegetation) and the animal rearing, means and resources, saving means and resources, reusing water and recycling nutrients from the animal manure and composting, among others (EPOCH TIMES 2016).

The Earthworm/Composting unit (Figure 4) will serve as an organic waste destination from the school, at the same time as it will provide fertilizer and slurry generation to potentiate agricultural production in the vegetable gardens. Composting unit is an efficient method to eliminate organic waste in schools and rural areas and is an aerobic process in which microorganisms degrade organic waste to nitrogen, and the composting quality depends on the organic waste type, composting procedure and time period (CPCB 2016).

There are great benefits to using composting in the school community, including the possibility for students to begin to manage and use the leftover food they and their families produce. Thus, learners are inevitably drawn to a broader ethical, personal responsibility and environmental citizenship, and take responsibility for the solid waste flow in schools, giving them a specific action to help their community and the Earth (Schwarz and Bonhotal 2017).

The earthworms production will be an alternative activity, which will use part of the waste generated by the school, the vegetable garden and the composting. The humus will be used in the seedbeds production, for the seedlings production and the earthworms as an alternative source of hens feeding, due to the low availability of space and manpower, becoming an alternative for the animal protein production, where the production system adopted will be 
through mobile hen house, also known as "chicken tractors". This name is linked to the hens' natural behavior of ground scattering, revolving their superficial layer. Due to facilities limiting pasture areas, they prevent hens from damaging crops
(Guelber Sales 2005). The mobile hen house (Figure 4) has space for maximum stocking of 4 to 5 hens per hen house, with dimensions of $2.08 \mathrm{~m}^{2}$ with two hens per $\mathrm{m}^{2}$.
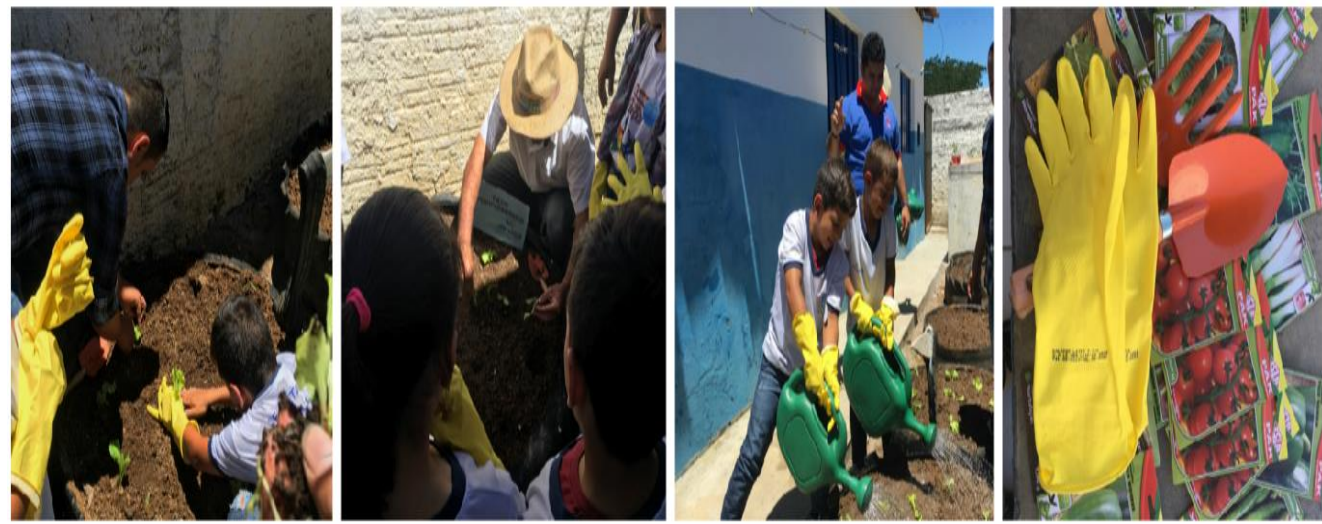

Figure 1 Planting with technical guidance.
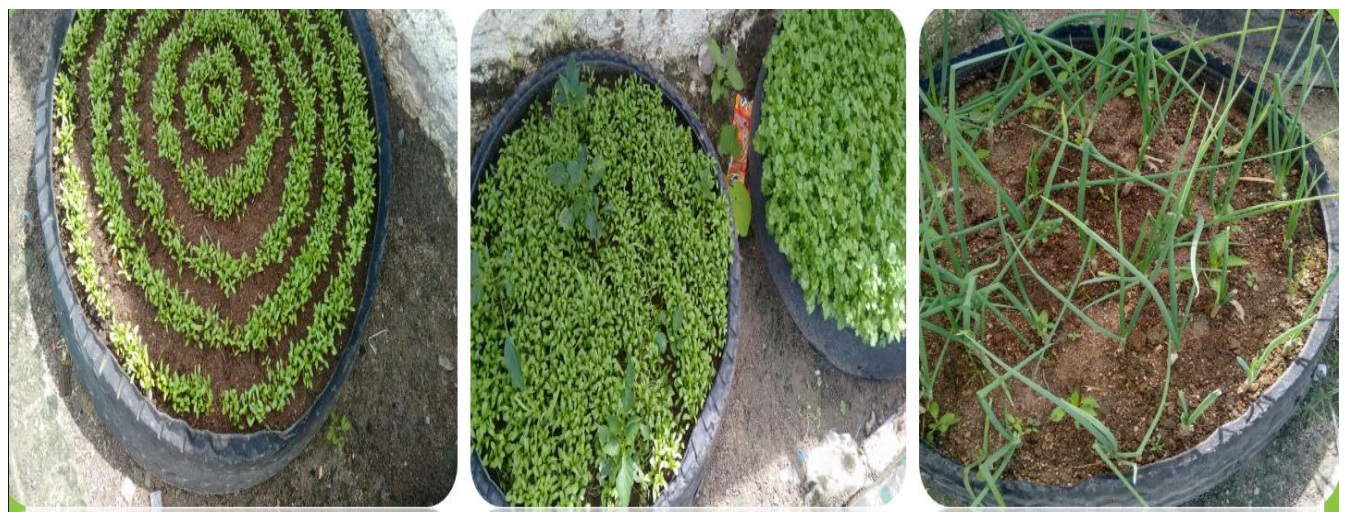

Figure 2 Vegetable garden with the use of tires.
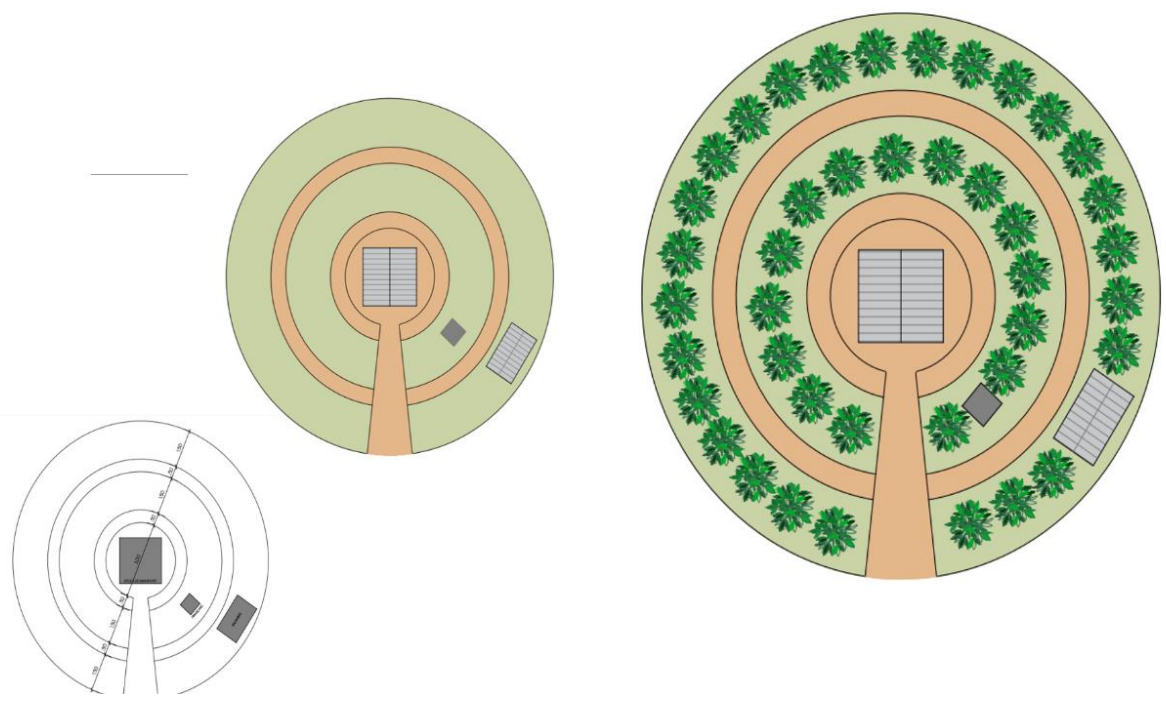

Figure 3 Mandala vegetable garden with equipment for animal and vegetable production. 

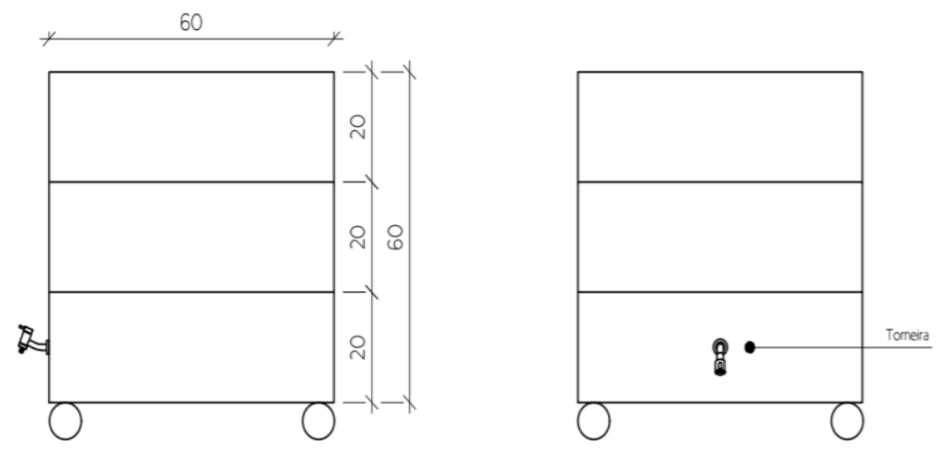

Figure 4 Earthworm/Composting unit.
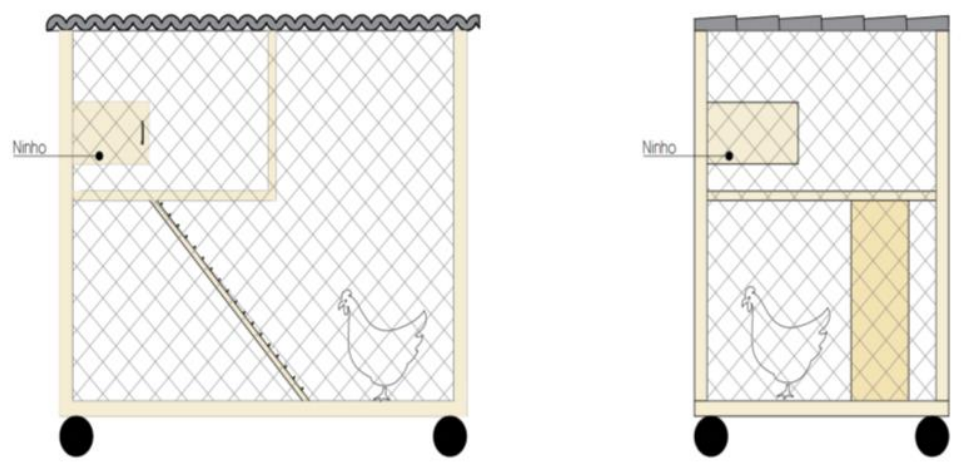

Figure 5 Mobile hen house.

To reduce the temperature inside the facilities, the roof will be covered with Tetra Pak boxes. According to Fiorelli et al (2010) this coverage type has been disseminated in zootechnical facilities, being manufactured from Tetra Pak ${ }^{\circledR}$ packaging, which besides being a form of reuse of this material, has thermal characteristics that favor its use in animal facilities, collaborating to reduce the temperature and thermal indices inside the facilities, thus favoring the animal comfort.

These facilities can add other advantages: the hens' manure deposition on the nursery bed, only in the place where the hen house is stopped, contributing for the fertility increase of the soil and the aeration realized by the hens in the scattering act.

The recyclable material chosen for use in the greenhouse construction was the PET bottle (Figure 6). With low cost and reuse of materials that would be discarded in the environment, was also used in the fruit trees seedlings production of easy adaptation to semi-arid.

According to Reis (2005), the Brazilian northeastern region is devoid of greenhouse models adapted to their climatic conditions, with high temperatures and low humidity. Sharma (2017) conducted a prototype study of greenhouse built with plastic bottles filled with sand like bricks, citing that there is difference between internal and external temperature when compared to plastic bottle in a normal greenhouse, both houses did not reach comfort zone at $30{ }^{\circ} \mathrm{C}$ to $34{ }^{\circ} \mathrm{C}$ for greenhouse and $29{ }^{\circ} \mathrm{C}$ to $34{ }^{\circ} \mathrm{C}$ for normal brick house. What can become ideal for the greenhouse, since the is important high temperature and high humidity.

For the control and future studies of climatology and ambience, two measurement equipment, a built-up pet bottle pluviometer (Figure 7), and a dry bulb and wet bulb thermometer were designed for temperature and humidity studies inside the greenhouse and in part outside the vegetable garden.

For Llorens and Domingos (2007) the rainfall studies in the vegetal production play an important role to determine the water balance in the local scale and its captations and modifications, both the evaporation and the redistribution of the incident rainfall.

The vegetable garden inserted in the school environment can be a living laboratory that allows the development of several pedagogical activities in environmental and food education, uniting theory and practice in a contextualized way, assisting in the teaching and learning process, and reducing elations through the promotion of collective and cooperative work among the social agents involved (Arruda et al 2017). 
It should be emphasized that this environment will be used to provide training to the community, providing knowledge on poultry, including sanitary management, feed preparation, records and notes, and the use of poultry manure for crop fertilization, vegetables and legumes production, and climatic studies.

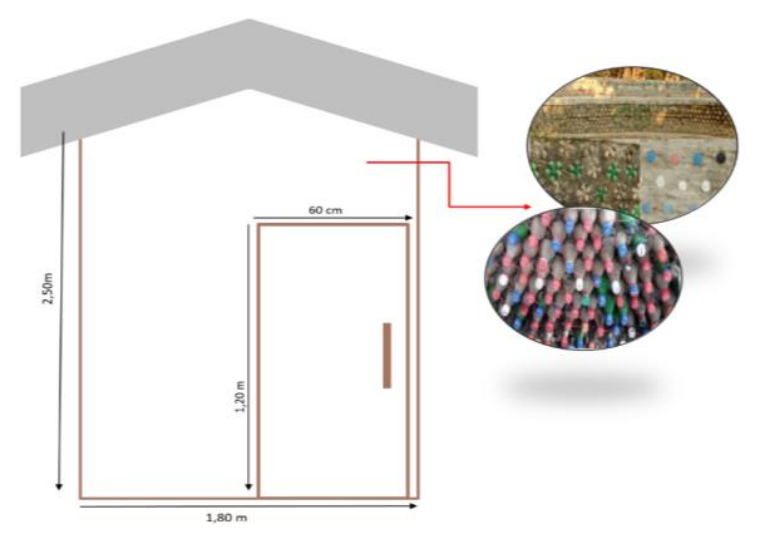

Figure 6 Greenhouse built from pet bottle.
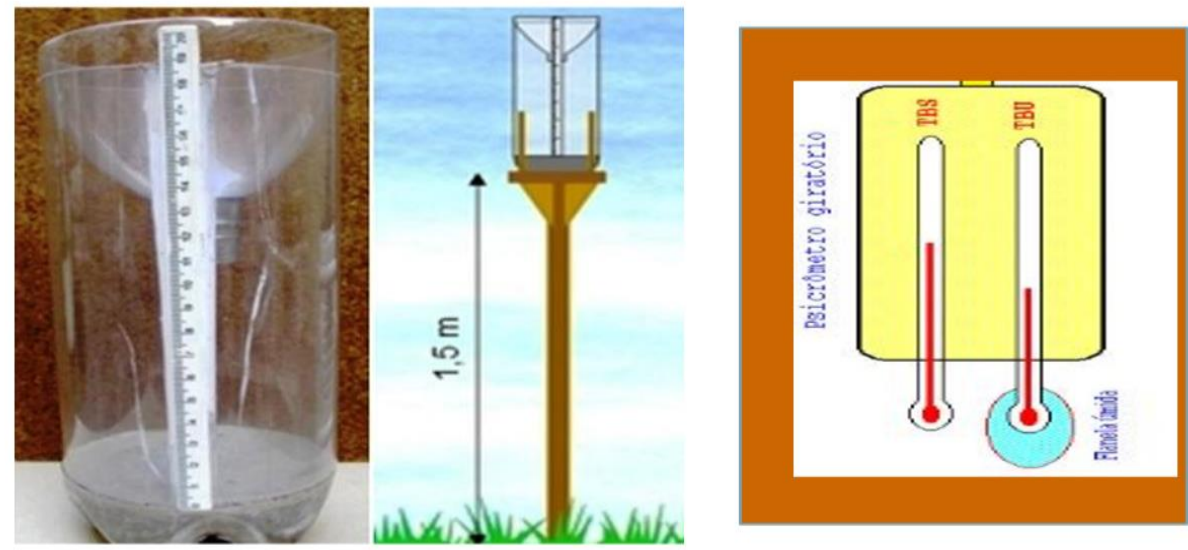

Figure 7 Climatological studies equipment.

In addition to providing better nutrition to the students at the school, that will host the project, it will also ensure greater awareness about natural assets and valued vision of agricultural activities so prevalent in the environment. The lack of incentive to the rural youth generates the noncontinuity of the properties and the growing demographic, economic and cultural depletion of regions where family agriculture predominates (Silvestro et al 2001; Anjos and Caldas 2015). According to Adeokun (2017), all stakeholders' efforts in sustainable child development are valid, and research remains a formidable way of to rationalize the alternatives agricultural and practices in school socializing.

This project was of great relevance to transform some aesthetic concepts such as the use of green spaces, actions aimed at environmental education, the possibility of exploring reusable resources were debated, used and artistically transformed into a vertical vegetable garden, which continues to be cared for by all students and school staff, as well as the study by Oliveira et al (2014).

\section{Conclusions}

With the objective of working environmental education and encouraging agricultural production in rural schools based on principles and guidelines based on good environmental conduits for animal and vegetable production, observed guidelines for the study were (1) sustainability in the ecological, economic, social, cultural, political and ethical dimensions; (2) agricultural production bringing welfare and ensuring productivity (3) low-cost construction and recyclable materials use.

Through this project it was possible to produce a system that would link agricultural production to school with conventional and mandala-style vegetable gardens; pet bottle greenhouse to the mandala center, producing seedlings to be 
destined to community, animal production a mobile hen house that will promote contact with the hens and meat and eggs production, and the fertilization possibility of nursery bed that still not in use; an Earthworm/Composting unit will also be an organic waste destination from the school kitchen turning into fertilizer.

Faced with this, it is possible to see that this model can provide information on important agricultural practices for productivity improvement of food from the school environment and be reaching the surrounding communities, guaranteeing a productive efficiency in the future.

\section{References}

Adeokun OA (2017) Research and Agricultural Extension Support for Sustainable Development of Nigerian Child: A General Over View. Journal of Sustainable Development 45:11-18.

Almeida VJ, Favetta LRA (2012) A Horta Mandala na Agrofloreta Sucessional: Uma Aliada na Restauração Ambiental. Revista Eletrônica Mestrado em Educação Ambiental 28:85-99.

Anjos FS, Caldas NV (2015) Ser ou não ser agricultor? Eis a questão. Representações sociais sobre a profissão de agricultor entre jovens de comunidade rural do Sul do Brasil. Revista de Extensão e Estudos Rurais 4:23-28.

Arruda RF, Marques MR, Reis JT (2017) Implantation of School Court Using Recyclable Materials as an Environmental Education Education Alternative. Interdisciplinary Scientific Journal 4:158176.

Ashrae R (2005) Programa de Educação Continuada - SMACNA. Understanding Psychrometrics $-2^{\text {th }}$ ed., p83.

Carvalho MBSS, Dalva MB, Bonotto DMB, Nardy TCDA (2017) Integração Curricular do Tema Agropecuária em uma Escola Municipal Agrícola: Sentidos Construídos. X Congreso internacional sobre investigación en didáctica de las ciencias. Enseñanza de las ciencias, $3175-3179$ https://argoseduca.congressus.es/congresoenseciencias. Accessed on: November 14, 2018.

Chandraa APDK, Caspe N, Dalabajanb MD (2017) A Study of Climate-Smart Farming Practices and Climate-resiliency Field Schools in Mindanao, the Philippines. World Development 98:214230.

CPCB (2009) Status of municipal solid waste generation, collection, treatment and disposal in main cities. Federation of Indian Chambers of Commerce and Industry. $3^{\text {th }} \mathrm{ed}$. New Delhi.

Fiorelli J, Fonseca, R, Morceli, JAB, DIAS A (2010) Influência de diferentes materiais de cobertura no conforto térmico de instalações para frangos de corte no oeste paulista. Revista de Engenharia Agrícola 30:986-992.

Guelber SMN (2005) Criação de galinhas em sistemas agroecológicos. Incaper. Vitória. $1^{\text {thed. p.284. }}$

Guthman J (2014) Agrarian Dreams: The Paradox of Organic Farming in California. $2^{\text {th }}$ ed. University of California, p.320.

Lorens P, Domingo F (2007) Rainfall partitioning by vegetation under Mediterranean conditions. A review of studies in Europe. Journal of Hydrology 335:37-54.

Nuttal C (2007) Agrofloresta para crianças: uma sala de aula ao ar livre. Instituto de Permacultura da Bahia. Salvador, $2^{\text {th }}$ ed. 80 .
Reis NVB (2005) Construção de estufas para produção de hortaliças nas Regiões Norte, Nordeste e Centro-Oeste. Embrapa. Brasília. 116. Available in: https://www.embrapa.br/busca-de-publicacoes//publicacao/779127/construcao-de-estufas-para-producao-de-

hortalicas-nas-regioes-norte-nordeste-e-centro-oeste. Accessed on: November 14, 2018.

Oliveira LHO, Abreu RF, Gobira MD, Assis GGD (2014) Horta Vertical: Um Instrumento de Educação Ambiental na Escola. Revista Eletrônica do Mestrado em Educação Ambiental, Rio Grande do Sul 1:193-206.

Pimenta JC, Rodrigues KSM (2011) Projeto Horta Escola. II Simpósio de Educação Ambiental e Transdisciplinaridade. Goiânia.2 thed. p. 11-18.

Salgueiro JHPB (2005) Avaliação de rede pluviométrica e análise de variabilidade espacial da precipitação: Estudo de Caso na bacia do Rio Ipojuca em Pernambuco. Recife. 16:1-122.

Silva ATA (2008) Aspectos meteorológicos e balanço hídrico em um aterro de resíduos sólidos urbanos 1-141. Available in: http://www.getres.ufrj.br/pdf/SILVA_ATA_08_t_M_int.pdf. Accessed on: November 14, 2018.

Silvestro ML (2001) Os impasses sociais da sucessão hereditária na agricultura familiar. Florianópolis. Editora EPAGRI. $1^{\text {th }}$ ed. 96p.

Schwarz M, Bonhotal J (2017) School Composting - Let's Get Growing. Soil and Crop Sciences 23:1-16.

Sharma H (2017) Innovative and Sustainable Application of PET Bottle a Green Construction Overview. Indian Journal of Science and Technology 10:1-6.

Saviani D (2008) Escola e Democracia. Campinas: Autores Associados.2008.

Tomio D, Andersen D, Schultz L (2017) The School as a Space for Educational and Research Practices in Permaculture: State of the Art of Scientific Production. Revista Eletrônica do Mestrado em Educação Ambiental, 34:12-18 